\title{
Flecked retina in systemic large-cell non-Hodgkin's lymphoma: case report
}

\author{
Retina com aspecto ponteado em um paciente com linfoma não-Hodgkin \\ de grandes células sistêmico: relato de caso
}

\author{
Raul N.G. Vianna ${ }^{1}$ \\ Acácio Muralha ${ }^{2}$ \\ Lília Muralha ${ }^{3}$ \\ Letícia Rielo de Moura ${ }^{4}$ \\ Miguel Nascentes Burnier Jr. ${ }^{5}$
}

\begin{tabular}{|l|}
\hline ABSTRACT \\
\hline We report on a patient with a past medical history of successfully treated \\
systemic large-cell non-Hodgkin's lymphoma (SNHL), who presented \\
with multifocal yellowish retinal infiltrates (flecked retina) involving the \\
post-equatorial retina of one eye. Fluorescein angiography revealed that \\
the retinal infiltrates were hypofluorescent throughout the examination. \\
The correct diagnosis of this ocular picture was important because the \\
retinal lesions indicated central nervous system recurrence of systemic \\
large-cell non-Hodgkin's lymphoma.
\end{tabular}

Keywords: Lymphoma, non-Hodgkin; Fluorescein angiography; Fundus oculi; Retina; Choroid; Recurrence; Cases report [Publication type]

\section{INTRODUCTION}

Ocular involvement in systemic large-cell non-Hodgkin's lymphoma (SNHL) is rare. However, when the eye is affected, the lymphomatous infiltration occurs primarily in the ciliary body and choroids ${ }^{(1)}$.

We report on a patient with a past medical history of SNHL, who presented with unilateral decreased vision associated with multifocal yellowish retinal infiltrates (flecked retina) involving the post-equatorial retina. The correct diagnosis of this ocular picture was important in our case because the retinal lesions indicated central nervous system (CNS) recurrence of SNHL.

\section{CASE REPORT}

A 54-year-old man was referred to our Retina Clinic complaining of acute loss of vision for seven days. His best-corrected visual acuity was $20 / 400$ in the right eye (RE) and 20/20 in the left eye (LE). Medical history revealed that the patient had finished chemotherapy to treat SNHL eight months before the onset of ocular symptoms. The patient also reported to be diabetic for approximately ten years.

Slit-lamp examination of the anterior segments was unremarkable. Intraocular tension was within normal limits in both eyes. Fundus examination of the RE showed a reticular pattern of yellowish clumping of pigment simulating fundus flavimaculatus at the level of the retina pigment epithelium (RPE) throughout the fundus (Figure 1). There was an area of subretinal white infiltration surrounding the foveal region, as well as dot and blot hemorrhages. The posterior vitreous showed a mild inflammatory response. There was sheathing of the retinal vessels near the white 
infiltrate. The left eye fundus showed few microaneurysms and dot hemorrhages.

Fluorescein angiography of the involved eye revealed that the pigment clumps were hypofluorescent throughout the examination, on a background of greater than normal fluorescence (Figure 2). An area of capillary drop-out was observed surrounding the fovea, which corresponded to the infiltrate seen on standard photograph. The hypofluorescent spots corresponded to retinal yellowish flecks. Angiograms of the LE revealed few microaneurysms and dot hemorrhages in the posterior pole. The diagnosis of retinal involvement secondary to SNHL was proposed and the patient was referred to oncology service. Further investigation indicated that the patient had a cervical lymphadenopathy and the retinal lesions were interpreted as a likely signs of CNS recurrence of SNHL. Cerebrospinal fluid revealed pre-
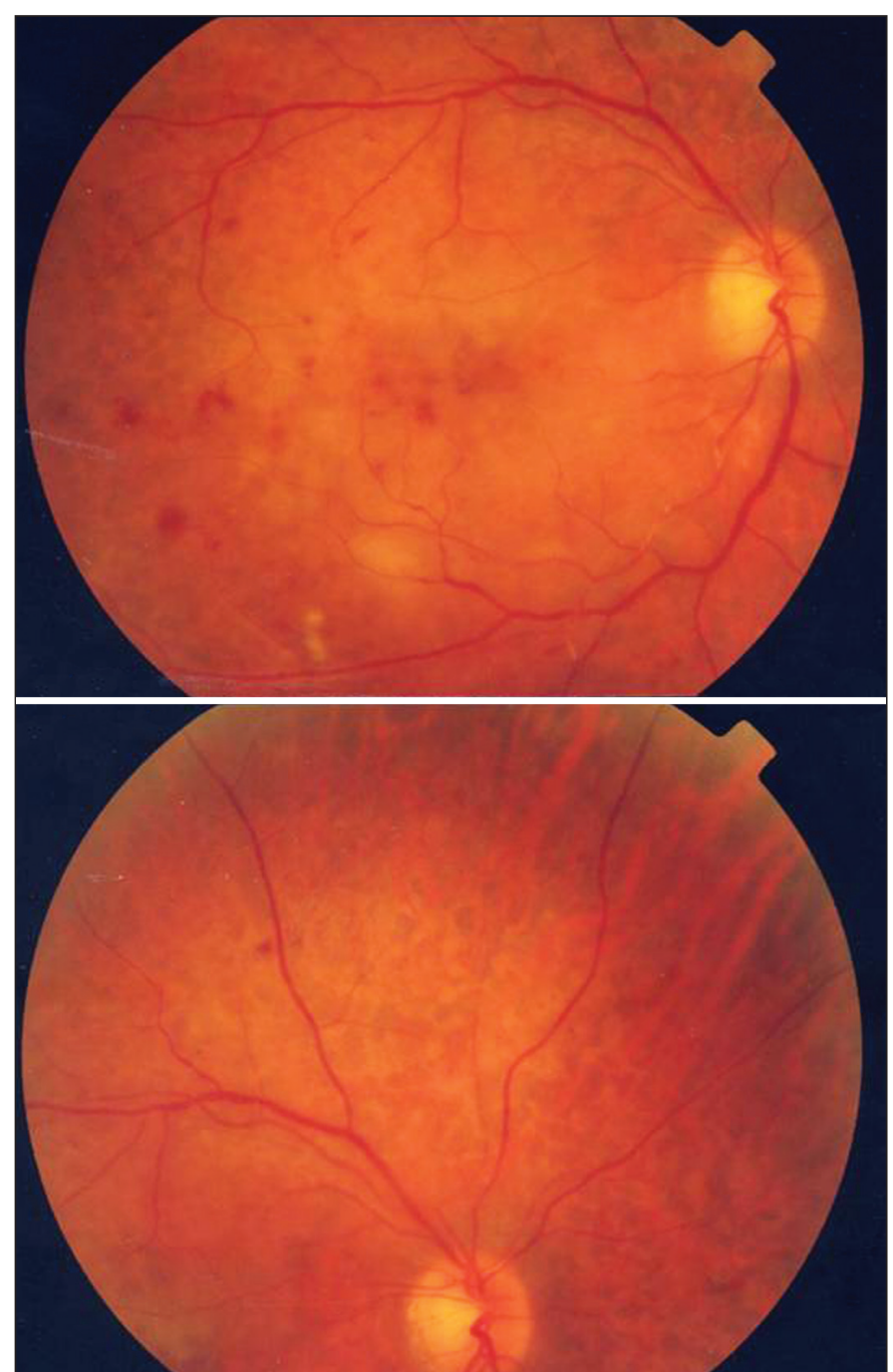

Figure 1 - Color pictures revealed a reticular pattern of yellowish pigment clumping simulating fundus flavimaculatus at the level of the retinal pigment epithelium; the posterior pole (top picture) and superior to the posterior pole (bottom picture). There are some dot and blot hemorrhages in the macular region. sence of neoplastic cells, which confirmed CNS involvement. The patient then started a new chemotherapy regimen. However, his general condition deteriorated, and he died soon afterward.

\section{DISCUSSION}

The ocular manifestations of the non-Hodgkin's lymphomas are usually infrequent and occur in two distinct settings: the systemic form and the primary ocular-CNS form ${ }^{(1)}$. Some authors compared the clinical features of these two types of ocular lymphomas and concluded that primary ocular-CNS occurs predominantly in women and is often bilateral ${ }^{(2)}$. Ocular inflammatory disease, particularly bilateral posterior uveitis with severe vitritis, is the typical initial clinical presentation. Nevertheless, some patients may present with solitary or multiple well-defined, creamy yellow fundus lesions, usually with a relatively clear vitreous ${ }^{(2)}$. These have been shown to be collections of lymphoma cells beneath the $\operatorname{RPE}^{(3)}$.

On the other hand, in the systemic form, the ocular involvement is often unilateral and the disorder most commonly affects men in the sixth decade of life and beyond. A choroidal mass and exophthalmos (due to orbital involvement) are the most common manifestations ${ }^{(2)}$. In fact, approximately $2 \%$ of all patients with systemic lymphoma have orbital disease, whereas $9 \%$ of all orbital tumors are lymphomas ${ }^{(4-5)}$.

Retinal hemorrhages and cotton-wool spots secondary to

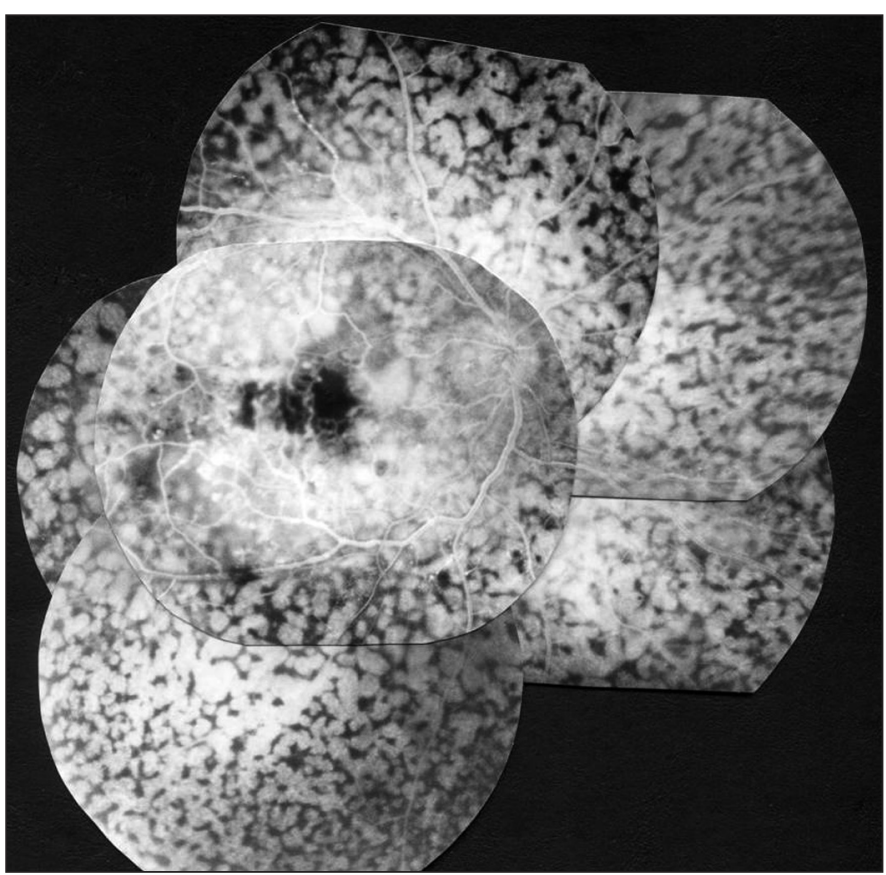

Figure 2 - Fluorescein angioagraphy showed the pigment clumps involved the entire fundus and were hypofluorescent since the early frames 
anemia and thrombocytopenia are relatively common in patients with SNHL, but direct retinal involvement is extremely $\operatorname{rare}^{(1)}$. However, in some cases a chorioretinal infiltration may produce a peculiar fundus picture composed of a reticular pattern of yellowish flecks simulating fundus flavimaculatus. Gass et al. described two patients with the symptom of a flecked retina simulating fundus flavimaculatus in one eye some months before developing signs and symptoms of systemic lymphoma ${ }^{(3)}$. Interestingly, Gass had already observed one SNHL patient with this particular ocular fundus in one eye and with multiple large sub-RPE tumors in his opposite eye, which is typical in the ocularCNS form of NHL. This fact demonstrates that there is an overlap in the two forms of large-cell non-Hodgkin lymphomas $^{(1)}$.

In our case the patient had already been treated for SNHL but eight months after chemotherapy he complained of decreased vision. We hypothesized that the decreased vision observed in our case was due to ischemic maculopathy secondary to diabetic retinopathy, worsened by the diffuse RPE involvement caused by the lymphoma.

The prognosis for survival in patients with SNHL and ocular manifestations is poor, but it may be improved with early and aggressive therapy ${ }^{(2)}$. In the present case, the patient died despite the early recognition of CNS involvement and adequate treatment.

The correct diagnosis of this ocular picture was important in our case because the retinal lesions indicated CNS recurrence of SNHL.

\section{RESUMO}

Relatamos um paciente com história patológica pregressa de linfoma não-Hodgkin sistêmico que oito meses após o tratamento apresentou quadro oftalmoscópico de múltiplos infiltrados retinianos amarelados ("flecked retina") envolvendo a retina pós-equatorial de um olho. A retinografia fluoresceínica revelou que os infiltrados retinianos eram hipofluorescentes durante todo o decorrer do exame. O diagnóstico correto desse quadro ocular foi importante, pois indicou recorrência do linfoma no sistema nervoso central.

Descritores: Linfoma não-Hodgkin; Angiofluoresceinografia; Fundus oculi; Retina; Coróide recidiva; Relatos de casos [Tipo de publicação]

\section{REFERENCES}

1. Gass JD. Neoplastic diseases of the retina and optic disc. In: Gasss JD. Stereoscopic atlas of macular diseases; diagnosis and treatment. $4^{\text {th }}$ ed. St Louis: CV Mosby; 1997. p.886-8.

2. George PD, McLean IW, Hidayat A, Keefe KS, Davidson JK, Burnier MN. Clinicopathologic differentiation of primary and secondary ocular lymphoma [abstract]. Invest Ophthalmol Vis Sci. 1993;34(suppl):970.

3. Gass JD, Weleber RG, Johnson DR. Non-Hodgkin's lymphoma causing fundus picture simulating fundus flavimaculatus. Retina. 1987;7(4):209-14.

4. Kennedy RE. An evaluation of 820 orbital cases. Trans Am Ophthalmol Soc. 1984;82:134-57.

5. Lazzarino M, Morra E, Rosso R, Brusamolino E, Pagnucco G, Castelo A, et al. Clinicopathologic and immunologic characteristics of non-Hodgkin's lymphomas presenting in the orbit: a report of eight cases. A report of eight cases. Cancer. 1985;55(9):1907-12. 